\title{
Serological grouping of streptococci by slide agglutination
}

\author{
ANDROULLA EFSTRATIOU AND W. R. MAXTED \\ From the Division of Hospital Infection, Central Public Health Laboratory, Colindale Avenue, \\ London NW9 5HT, UK
}

SUMMARY Streptococcal grouping sera for groups A, B, C, and G prepared for conventional testing by precipitation were made specific by absorption and used to identify streptococci by slide agglutination with and without staphyloccocal coagglutination. Trypsinised suspensions of 1055 strains, identified by precipitation as belonging to group A, B, C, or G, were tested by slide agglutination. Of these, 998 were correctly identified using a streptococcal suspension and antisera alone and a further 65 were identified when a loopful of protein A-positive staphylococci was addecl. Suspensions of 88 strains not of groups A, B, C, or G gave no reaction in the agglutination test with or without the addition of staphylococci. Group polysaccharide extracted by conventional methods also caused agglutination of staphylococci on a slide when specific antiserum was added.

Growth from primary or secondary cultures digested in streptomyces enzyme for only 15-30 minutes provided an excellent antigen for a quick and simple method of streptococcal grouping using non-sensitised staphylococcal suspension and specific antisera for coagglutination.

The serological grouping of streptococci is not performed as frequently as it should be, perhaps because the techniques are slow and the reagents costly. Attempts have been made to overcome these drawbacks (Dajani, 1973; El Kholy et al., 1974). More recently, attention has centred on an agglutination technique as a streptococcal grouping procedure (Christensen et al., 1973; Edwards and Larson, 1974; Hryniewicz et al., 1976; Tebbutt et al., 1976). Slide agglutination, as described by Rosendal (1956), is still used successfully in Denmark, but elsewhere the commercially available grouping antisera intended for use in precipitation are not sufficiently specific for the more sensitive agglutination test, and the method failed to gain wide popularity.

Pharmacia Ltd produce a coagglutination kit (Phadebact) for streptococcal grouping. However, the reagents are expensive and the shelf-life comparatively short. It employs a suspension of Staphylococcus aureus rich in protein A to which the group antibody is non-specifically absorbed. When mixed on a slide with a suspension of a streptococcus of the homologous group, rapid coarse agglutination follows. Group antigen is also found in the supernates

Received for publication 23 July 1979 of broth cultures of streptococci and may be used for coagglutination (Hill et al., 1975; Rosner, 1977).

We have reassessed the slide agglutination techniques with a view to incorporating some features of each in a method that would be simple, specific, rapid, and economical (Maxted et al., 1976; Efstratiou and Maxted, 1979).

\section{Material and methods}

STRAINS

Streptococci for slide agglutination were laboratory strains of each of the Lancefield groups A-S or cultures from clinical material submitted to the Streptococcal Reference Department for routine identification.

The streptococcal strains used for absorption of the antisera were: group A type 1 NCTC 8198 , and R76/2929 (with type 28R antigen), group C NCTC 8545 , and group G NCTC 9603 . The staphylococci were the Cowan I Staph. aureus strain NCTC 8530 and a laboratory strain ST78/5620 (phage type $29 / 23 \mathrm{~A} / 85 /+$ ).

\section{MEDIUM}

Nutrient Broth No. 2 (Oxoid) plus glucose $5 \mathrm{~g} / \mathrm{l}$, $\mathrm{Na}_{2} \mathrm{HPO}_{4} 4 \cdot 325 \mathrm{~g} / \mathrm{l}$, and $\mathrm{KH}_{2} \mathrm{PO}_{4} \mathbf{0} \cdot 385 \mathrm{~g} / \mathrm{l}$ was used to grow the streptococci used for absorption of the 
antisera. All bacterial suspensions used for the slide agglutination test were grown in Todd Hewitt Broth (Difco).

TRYPSIN SOLUTION

A saturated solution of trypsin was made by adding $10 \% \mathrm{w} / \mathrm{v}$ of trypsin powder Difco ' $1 / 250$ ' in $0.1 \mathrm{M}$ phosphate buffer $\mathrm{pH} 7 \cdot 8$. After centrifugation to remove the insoluble residue, the trypsin supernate was sterilised by filtration through a Millipore filter $\left(0.45 \mu\right.$ porosity) and stored at $-20^{\circ} \mathrm{C}$. The activity of the solution was determined by placing one drop of each of a series of 10-fold dilutions made in the phosphate buffer onto a strip of exposed, developed, and fixed photographic film, and incubating it in a moist chamber at $37^{\circ} \mathrm{C}$ for 1 hour. The film was then rinsed in water. The highest dilution showing a completely clean area of digestion on the film was taken as the end point. The titre should not be less than $10^{4}$.

\section{PREPARATION OF STAPHYLOCOCCAL} SUSPENSION

(1) The staphylococcal suspensions were washed five times in phosphate-buffered saline (PBS $=0.03 \mathrm{M}$ phosphate, $0 \cdot 12 \mathrm{M} \mathrm{NaCl} \mathrm{pH} 7 \cdot 3$, with $0.1 \%$ sodium azide added as a preservative). The washed bacteria were suspended in $0.5 \%$ formaldehyde in PBS and left at room temperature for 3-4 hours. After three washings the staphylococci were suspended at a concentration of $10 \%(\mathrm{v} / \mathrm{v})$ in buffer and heated at $80^{\circ} \mathrm{C}$ for 1 hour. After washing a further three times a $10 \%(\mathrm{v} / \mathrm{v})$ suspension of the staphylococcal growth was made in PBS and stored at $4^{\circ} \mathrm{C}$. This had an optical density of 0.33 at $540 \mathrm{~nm}$ at a dilution of $1 / 100$.

(2) A crude suspension was prepared by growing the staphylococcus in $200 \mathrm{ml}$ Todd Hewitt broth overnight at $37^{\circ} \mathrm{C}$, centrifuging, and heating the bacterial deposit suspended in saline at $60^{\circ} \mathrm{C}$ for 45 minutes. The cells were then washed once in physiological salt solution and resuspended in $0.1 \mathrm{M}$ phosphate buffer at $\mathrm{pH} 7.8$ to the same optical density. The staphylococcal suspension remained active for at least 10-12 weeks when preserved with thiomersal $(0.002 \% \mathrm{w} / \mathrm{v})$ and kept at $4{ }^{\circ} \mathrm{C}$. The suspension may be freeze-dried for longer storage.

ABSORPTION OF ANTISERA

A series of two-fold dilutions in saline was made for each grouping serum. These were tested by slide agglutination against a trypsinised suspension of the homologous group. The working dilution was half of that which showed a vigorous agglutination reaction within 1 minute $(\mathrm{a}++$ reaction). Each serum at its working dilution was tested against trypsinised suspensions of representatives from each of the Lancefield groups. Sera giving cross-reactions were absorbed with a suspension of the appropriate strain using the method described by Williams (1958).

In this study the sera were absorbed at half their working dilution, group A being absorbed with a group C suspension, group B with the group A 28R and group $G$ suspensions, and group $C$ with the group $A$ type 1 suspension. The group $G$ antiserum was specific after dilution and did not require absorption.

PREPARATION OF ABSORBING SUSPENSIONS Streptococci grown in 4-litre volumes of broth for 48 hours at $37^{\circ} \mathrm{C}$ were killed by heating at $60^{\circ} \mathrm{C}$ for 30 minutes. The cells were centrifuged and washed twice in $40 \mathrm{ml}$ of physiological saline and resuspended in $40 \mathrm{ml}$ of phosphate buffer $\mathrm{pH} 7.8$ containing $5 \%$ $(\mathrm{v} / \mathrm{v})$ sterile trypsin and left to digest at room temperature overnight. After a further six washings in saline the cells were resuspended in $40 \mathrm{ml}$ of phosphate buffer and steamed at $100^{\circ} \mathrm{C}$ for 1 hour.

PREPARATION OF STREPTOCOCCAL AGGLUTINATING SUSPENSIONS

Various methods of digestion were tried.

(1) The streptococci were grown in $5 \mathrm{ml}$ of broth overnight at $37^{\circ} \mathrm{C}$. The tubes were centrifuged and all but about $0.3 \mathrm{ml}$ of the supernate was removed. To this 2-3 drops of a $10 \%$ trypsin solution were added. The suspension was adjusted to $\mathrm{pH} 8.0$ and incubated at $37^{\circ} \mathrm{C}$ until it was no longer granular (1-2 hours).

(2) The streptococci were inoculated into $5 \mathrm{ml}$ of broth containing a final concentration of $0.6 \%(\mathrm{v} / \mathrm{v})$ sterile trypsin and incubated at $30^{\circ} \mathrm{C}$ overnight. After centrifugation the deposit was resuspended and used directly in the test.

(3) Colonies from blood agar plates were suspended in $0.4 \mathrm{ml}$ of phosphate buffer $\mathrm{pH} 8.0$, and $0.1 \mathrm{ml}$ of trypsin solution $(5 \mathrm{mg} / \mathrm{ml})$ was added and incubated at $37^{\circ} \mathrm{C}$ until the suspension was smooth (Tebbutt et al., 1976).

(4) Colonies from blood agar plates were suspended in $0.3 \mathrm{ml}$ crude streptomyces enzyme solution and digested at $50^{\circ} \mathrm{C}$ for $15-30$ minutes.

\section{GROUPING EXTRACTS}

Acid extracts were prepared by the Lancefield (1933) method, formamide extracts were made by Fuller's (1938) technique, and the streptomyces enzyme extracts by the method described by Maxted (1948).

GROUPING SERA

Two sets of antisera, both prepared for use in the 
precipitation test for groups A, B, C, and G, were studied. One was prepared by the Streptococcal Reference Department and the other by Wellcome Reagents Ltd.

\section{SLIDE AGGLUTINATION TEST}

The procedure is as follows:

(1) Four drops (from a $5 \mathrm{~mm}$ loop or a $0.02 \mathrm{ml}$ dropping pipette) of the trypsinised streptococcal suspension are placed on a slide. A small $(3 \mathrm{~mm})$ loopful of each of the sera is added to the suspension and the slide is rocked for $30-40$ seconds, by which time specific agglutination is visible if it is to take place.

(2) If agglutination is absent or doubtful a small ( $3 \mathrm{~mm}$ ) loopful of staphylococcal suspension is added to each drop in turn, and the slide is rocked again for approximately 15 seconds. By this means, weak agglutination is often increased, and an occasional additional reaction appears.

(3) If a reaction is not obtained the order of addition of reagents is reversed.

\section{Results}

Grouping sera made in this laboratory were tested by slide agglutination against trypsinised suspensions of representative strains of each of the groups A, B, $\mathrm{C}$, and $\mathrm{G}$ to determine the titre for several members of the homologous types and for the presence of heterologous reactions (Table 1). This table shows that single absorption with the appropriate strain removed any cross-reactions. Tenfold dilution of group $G$ serum was sufficient to eliminate the heterologous reaction with group $B$.

The absorbed diluted sera were tested extensively against suspensions of 275 strains that had been shown to belong to the groups A, B, C, or G by the conventional grouping method performed in doublegel diffusion slides (Ouchterlony, 1953) and also on suspensions of 51 strains belonging to other groups (Table 2). These 51 strains comprised representatives of groups D, E, F, and K and also Strep. sanguis strains (5), Strep. mitior (4), Strep. milleri (19), and eight unidentified strains of streptococci. None of the 51 strains that were not group A, B, C, or G reacted with the antisera even with the addition of staphylococcal suspension.

All the 275 groupable strains were identified correctly by slide agglutination, and, of these, 263 $(95.7 \%)$ were diagnosed by slide agglutination using antiserum alone and only $12(4.4 \%)$ needed the addition of staphylococcal suspension to demonstrate the group reaction. Over half these strains

Table 1 Absorption of grouping sera for use in the slide agglutination test

\begin{tabular}{|c|c|c|c|c|}
\hline Antisera & $\begin{array}{l}\text { Homologous } \\
\text { reaction }\end{array}$ & $\begin{array}{l}\text { Heterologous } \\
\text { reaction with } \\
\text { group: }\end{array}$ & $\begin{array}{l}\text { Heterologous } \\
\text { reactions removed } \\
\text { by absorption with } \\
\text { cells of strain }\end{array}$ & $\begin{array}{l}\text { Specific } \\
\text { homologous } \\
\text { titre after } \\
\text { absorption }\end{array}$ \\
\hline $\begin{array}{l}\text { Group A } \\
\text { Group B }\end{array}$ & $\begin{array}{l}+++ \\
++t\end{array}$ & $\begin{array}{l}\mathbf{C}+++ \\
\mathbf{A}(\mathbf{2 8 R})+++ \\
\mathbf{G}+++ \\
\mathbf{E}+++ \\
\mathbf{L} \pm \\
\mathbf{S} \pm\end{array}$ & $\begin{array}{l}\text { Group C Chestle } \\
\text { Group G Valente } \\
\text { Group A 28R }\end{array}$ & 15 \\
\hline $\begin{array}{l}\text { Group C } \\
\text { Group G }\end{array}$ & $\begin{array}{l}+++ \\
+++\end{array}$ & $\begin{array}{l}\mathbf{A}++ \\
\mathbf{B}+++\end{array}$ & $\begin{array}{l}\text { Group A type } 1 \\
\text { Absorption not necessary. } \\
\text { Dilution only }\end{array}$ & $\begin{array}{l}15 \\
32\end{array}$ \\
\hline
\end{tabular}

$\pm \longrightarrow+++$ degree of agglutination reaction.

Table 2 Streptococcal grouping by slide agglutination with absorbed Colindale sera

\begin{tabular}{|c|c|c|c|c|c|}
\hline \multirow{2}{*}{$\begin{array}{l}\text { Strains of } \\
\text { Lancefield } \\
\text { group }\end{array}$} & \multirow{2}{*}{$\begin{array}{l}\text { Number } \\
\text { tested }\end{array}$} & \multicolumn{2}{|c|}{ Reactions using serum alone* } & \multicolumn{2}{|c|}{ Additional reaction with staphylococcus added* } \\
\hline & & No. & $\%$ & No. & $\%$ \\
\hline $\begin{array}{l}\text { A } \\
\text { B } \\
\text { C } \\
\text { G } \\
\text { Other }\end{array}$ & $\begin{array}{r}210 \\
32 \\
11 \\
22 \\
51\end{array}$ & $\begin{array}{r}205 \\
25 \\
11 \\
22 \\
0\end{array}$ & $\begin{array}{r}98 \\
78 \\
100 \\
100\end{array}$ & $\begin{array}{l}5 \\
7 \\
0 \\
0 \\
0\end{array}$ & $\begin{array}{r}2 \\
22\end{array}$ \\
\hline Total & 326 & 263 & 95.6 & 12 & $4 \cdot 4$ \\
\hline
\end{tabular}

*There were no heterologous reactions. 
(7 of 12) belonged to group B and were serotype II. While the trypsinisation methods used for the preparation of the streptococcal suspensions were equally efficient, growing the cultures in broth to which trypsin had been added (method 2) was least trouble, as the trypsin broth could be prepared well in advance, and approximately $90 \%$ of the cultures were smooth after overnight incubation. Suspensions that were not, were retrypsinised for a short period.

The performance of the commercial sera was so similar to that of those from Colindale that they were diluted and absorbed in the same way and used to test suspensions of 815 streptococci received for identification. Of these, 778 had been identified by conventional grouping methods as belonging to groups A, B, C, or G. The remaining 37 strains included members of groups D, E, F, K, and S and some representatives of Strep. sanguis, Strep. milleri, and Strep. mitior. The slide agglutination method identified correctly all the 778 strains that belonged to groups A, B, C, or G (Table 3). The antisera gave no reactions with any suspensions of the 37 strains that did not belong to the four primary groups.

Although the major part of this work was done using the formalin-fixed staphylococcal suspension, tests were also done in parallel using a crude suspension that had been washed only once and was not formolised. The performance of the two preparations in coagglutination tests was very similar, but the formalin-fixed suspension was more stable. However, the cruder preparation is satisfactory if the staphylococcal suspension is renewed every four to six weeks. All streptococcal suspensions of known groups A, B, C, and G strains responded to trypsin treatment and gave smooth suspensions. Group B suspensions were nearly always smooth and did not need trypsinisation before use. Suspensions of colonies from blood agar plates trypsinised as described by Tebbutt et al. (1976) gave results similar to those with broth suspensions, but agglutination was more easily seen when staphylococcal suspension was added. Although Staph. aureus Cowan type I was used for most of the work, we also used Staph. aureus strain 5620 for the work with extracted antigen. This staphylococcus was particularly stable in its protein A content, in spite of subculture, whereas the Cowan I strain produced protein A negative variants rather readily.

Because it seemed likely that conventional streptococcal grouping extracts would also give a positive agglutination reaction in these tests (Hill et al., 1975) a total of 65 strains were tested using streptomyces enzyme, formamide, and Lancefield acid extracts for each strain. Vigorous agglutination occurred with the homologous serum. The three types of extract were all equally successful. This method provides a specific, rapid, and economical way of testing conventionally prepared grouping extracts.

In the modification of the streptomyces enzyme technique suspensions of streptococcal growth from blood agar plates were digested for 15-30 minutes. All strains were correctly identified. The technique was applied to pure growth of streptococci and to mixed cultures as from throat swabs. The enzymecoagglutination reactions agreed with the conventional grouping results, but 41 strains were not groupable by any method (Table 4). This method is very sensitive and a small amount of antigen suffices. We encountered some minor cross-reactions, not seen when whole-cell suspensions were used, but these non-specific antibodies were easily removed. The minor cross-reactions were seen initially with antisera of groups A and G, notably with strains of group B streptococci belonging to serotype Ib. This cross-reaction was easily removed by absorption with

Table 3 Streptococcal grouping using the slide agglutination test with commercially prepared antisera that had been absorbed in our laboratory

\begin{tabular}{|c|c|c|c|c|c|}
\hline \multirow{2}{*}{$\begin{array}{l}\text { Lancefield } \\
\text { group }\end{array}$} & \multirow{2}{*}{$\begin{array}{l}\text { Number } \\
\text { tested }\end{array}$} & \multicolumn{2}{|c|}{ Reactions using serum alone* } & \multicolumn{2}{|c|}{ Additional reactions with staphylococcus added * } \\
\hline & & No. & $\%$ & No. & $\%$ \\
\hline $\begin{array}{l}\mathbf{A} \\
\mathbf{B} \\
\mathbf{C} \\
\mathbf{G}\end{array}$ & $\begin{array}{r}600 \\
84 \\
33 \\
61\end{array}$ & $\begin{array}{r}569 \\
63 \\
32 \\
61\end{array}$ & $\begin{array}{r}94 \cdot 8 \\
75 \cdot 0 \\
97 \cdot 0 \\
100 \cdot 0\end{array}$ & $\begin{array}{c}31 \dagger \\
21 t \\
1 \\
0\end{array}$ & $\begin{array}{r}5 \cdot 2 \\
25 \cdot 0 \\
3 \cdot 0\end{array}$ \\
\hline $\begin{array}{l}\text { Total } \\
\text { Others }\end{array}$ & $\begin{array}{r}778 \\
37\end{array}$ & $\begin{array}{r}725 \\
0\end{array}$ & $93 \cdot 2$ & $\begin{array}{r}53 \\
0\end{array}$ & $6 \cdot 8$ \\
\hline Total & 815 & & & & \\
\hline
\end{tabular}

*There were no heterologous reactions.

tGroup A type 28R strains (25).

" " 2 " (4).

" " prov. type '3354' strains (2).

‡Group B type II. 
Table 4 Slide agglutination grouping using streptomyces enzyme digests

\begin{tabular}{|c|c|c|c|c|c|c|}
\hline \multirow[t]{2}{*}{ Growth from } & \multirow{2}{*}{$\begin{array}{l}\text { Number of } \\
\text { streptomyces } \\
\text { digests tested }\end{array}$} & \multicolumn{4}{|c|}{ Positive agglutination with antiserum of group: } & \multirow[t]{2}{*}{ No reaction } \\
\hline & & $A$ & $B$ & $C$ & $\boldsymbol{G}$ & \\
\hline $\begin{array}{l}\text { Primary throat swab plates } \\
\text { Pure cultures }\end{array}$ & $\begin{array}{r}319 \\
36\end{array}$ & $\begin{array}{r}194 \\
10\end{array}$ & $\begin{array}{r}17 \\
4\end{array}$ & $\begin{array}{l}32 \\
12\end{array}$ & $\begin{array}{l}35 \\
10\end{array}$ & $\begin{array}{c}41 * \\
0\end{array}$ \\
\hline
\end{tabular}

*These strains were not groupable by conventional methods.

one of these strains. As an additional precaution the antisera were also tested with the staphylococcal suspension alone and with the streptomyces enzyme to ensure their specificity. The method closely resembles the Streptex (Wellcome Reagents Ltd) technique where supernates of digests of streptococcal suspensions are used to agglutinate latex particles precoated with group antibody (Farrar and Paul, 1979).

\section{Discussion}

It is probable that the comparatively short shelf-life of suspensions of staphylococci sensitised with antibody is due to the gradual loss of antibody from the staphylococcal cell wall due to a leaching process. One aim of our study was to explore the possibility of adding a protein A-containing staphylococcus directly to the mixture of antigen and antibody on the slide, thus sensitising the staphylococci and obtaining coagglutination by a single process. The second aim was to prepare specific grouping antisera that could be used diluted and so keep the cost of reagents to a minimum.

The simple absorption procedure used in preparing the antisera was successful with the strains of streptococci with which they were tested. It may be that further testing of larger numbers of streptococci will reveal some unusual cross-reactions. However, the results so far seem to encourage the extension of the range of grouping sera used in the test to other groups.

Two sets of grouping antisera prepared in separate laboratories were used in the study. These sera were so similar in both their homologous titre and their pattern of heterologous reactions that it seems reasonable to consider their performance as one study. All 1053 strains known to belong to groups A, B, C, or G were successfully identified by slide agglutination. Most of these were agglutinated using antiserum alone, and only $65(6 \%)$ required the addition of a staphylococcal suspension to demonstrate the reaction. Many of the latter belonged to group B type II, while of the group A strains the majority contained the type $28 \mathrm{R}$ antigen. It may be that such strains have an additional blocking antigen that prevented agglutination of the streptococcal cells when tested with antiserum alone. However, because they reacted so readily when staphylococcal suspension was added it is clear that some specific antibody has been absorbed to the streptococcal surface.

Efficient trypsinisation of the streptococcal suspension was essential for all tests. Inadequately treated suspensions autoagglutinate, and this can be misinterpreted as positive agglutination if adequate controls are not included. The trypsinisation method that proved most useful was growth overnight at $37^{\circ} \mathrm{C}$ in broth containing trypsin.

Tebbutt et al. (1976) showed that it is possible to group strains successfully by coagglutination using a trypsinised suspension of colonies taken direct from a primary plate. This was also possible using the agglutination technique described here, but in addition we were also successful when testing colonies treated with streptomyces enzyme for a short time. An advantage of using the enzyme digestion is that streptococcal group polysaccharide is released from the cell and this reacts with the homologous antiserum and gives agglutination in the presence of a protein A positive staphylococcal suspension. It is thus possible to identify the group polysaccharide from mixed growth of streptococci and other organisms taken directly from blood agar plates because only the streptococci are lysed, and the free polysaccharide is available to take part in the coagglutination reaction. Although it could be used only in coagglutination, the short-term digestion technique had several advantages. It was very quick, and diagnosis could often be made with a minimum of labour within 30 minutes of scanning the primary plate. As expected, streptococcal grouping extracts prepared for conventional precipitation grouping methods also gave excellent homologous agglutination irrespective of the extraction method used to prepare them. This method of doing the test had some advantage over conventional precipitation methods. The layering method is uneconomical of antiserum and needs special tubes. The immunoelectrophoresis and double gel diffusion techniques both require the preparation of gel-slides, and the result is delayed, $\mathbf{3 0}$ minutes with immuno- 
electrophoresis and 5-18 hours with the gel-diffusion method. All the modifications of coagglutination we have used are simple to perform and the results are read immediately. A commercial source of suitable antisera has proved convenient, and because these sera can be diluted for use the method is attractive economically. The need to absorb the sera is an inconvenience, but the strict specificity which results is a considerable advantage, and it is hoped that similar specific group antisera will become available commercially.

\section{References}

Christensen, P., Kahlmeter, G., Jonsson, S., and Kronvall, G. (1973). New method for the serological grouping of streptococci with specific antibodies adsorbed to protein A-containing staphylococci. Infection and Immunity, 7, 881-885.

Dajani, A. S. (1973). Rapid identification of beta-hemolytic streptococci by counterimmunoelectrophoresis. Journal of Immunology, 110, 1702-1705.

Edwards, E. A., and Larson, G. L. (1974). New method of grouping beta-hemolytic streptococci directly on sheep blood agar plates by coagglutination of specifically sensitised protein A-containing staphylococci. Applied Microbiology, 28, 972-976.

Efstratiou, A., and Maxted, W. R. (1979). Use of slide agglutination and coagglutination methods for grouping streptococci. In Pathogenic Streptococci, edited by M. T. Parker, pp. 254-255. Reedbooks, Chertsey, Surrey.

El Kholy, A., Wannamaker, L. W., and Krause, R. M. (1974). Simplified extraction procedure for the serological grouping of beta-hemolytic streptococci. Applied Microbiology, 28, 836-839.

Farrar, J. L., and Paul, A. (1979). Grouping of streptococci by means of latex particles coated with antibody. In Pathogenic Streptococci, edited by M. T. Parker, p. 256. Reedbooks, Chertsey, Surrey.

Fuller, A. T. (1938). The formamide method for the extraction of polysaccharides from haemolytic strep- tococci. British Journal of Experimental Pathology, 19, 130-139.

Hill, L. R., Riter, M. E., Merge, S. K., Johnson, D. R., and Matsen, J. M. (1975). Rapid identification of group B streptococci by counterimmunoelectrophoresis. Journal of Clinical Microbiology, 1, 188-191.

Hryniewicz, W., Heczko, P. B., Lütticken, R., and Wannamaker, L. W. (1976). Comparison of three methods for grouping streptococci. Journal of Clinical Microbiology, 4, 28-31.

Lancefield, R. C. (1933). A serological differentiation of human and other groups of hemolytic streptococci. Journal of Experimental Medicine, 57, 571-595.

Maxted, W. R. (1948). Preparation of streptococcal extracts for Lancefield grouping. Lancet, 2, 255-256.

Maxted, W. R., Efstratiou, A., and Parker, M. T. (1976). Agglutination grouping of streptococci (Letter). Lancet, 2, 692-693.

Ouchterlony, O. (1953). Antigen-antibody reactions in gels. IV. Types of reactions in coordinated systems of diffusion. Acta Pathologica et Microbiologica Scandinavica, 32, 231-240.

Rosendal, K. (1956). Grouping of hemolytic streptococci belonging to groups $\mathrm{A}, \mathrm{C}$ and $\mathrm{G}$ : a comparison between the results obtained by precipitation and by slide agglutination. Acta Pathologica et Microbiologica Scandinavica, 39, 127-136.

Rosner, R. (1977). Clinical evaluation of a rapid four hour serological grouping of groups A, B, C and G beta-streptococci using the Phadebact streptococcus test. Journal of Clinical Microbiology, 6, 23-26.

Tebbutt, G. M., Coleman, D. J., and McGhie, D. (1976). Grouping of beta-hemolytic streptococci with groupspecific antibodies adsorbed to staphylococcal protein A. Journal of Clinical Pathology, 29, 1085-1087.

Williams, R. E. O. (1958). Laboratory diagnosis of streptococcal infections. Bulletin of the World Health Organisation, 19, 153-176.

Requests for reprints to: Miss Androulla Efstratiou, Division of Hospital Infection, Central Public Health Laboratory, Colindale Avenue, London NW9 5HT, UK. 